\title{
Preparation of a Modified Octadecyl Silica Membrane Disk for Solid Phase Extraction of Lead(II) lons in Different Real Samples and their Determination with ICP-AES
}

\author{
Mohammad Reza Pourjavid ${ }^{\mathrm{a}, \mathrm{b},{ }^{*}}$ and Ali Akbari Sehat ${ }^{\mathrm{c}, \#}$
}

${ }^{a}$ NFCRS, Nuclear Science \& Technology Research Institute, AEOI, P.O. Box 11365-8486, Tehran, Iran

${ }^{b}$ Department of Medicinal Chemistry, Pharmaceutical Sciences Branch, Islamic Azad University, Tehran, Iran

${ }^{c}$ Department of Analytical Chemistry, Faculty of Chemistry, University College of Science, University of Tehran, P.O. Box 14155-6455, Tehran, Iran

\begin{abstract}
A solid phase extraction and inductively coupled plasma atomic emission spectrometry (ICP-AES) for the determination of lead(II) ions with octadecyl-bonded silica membrane disks modified by 4-methyl-N-\{2-(4methylbenzothioyl)aminoethyl\}benzenecarbothioamide (MMAB) was studied. Extraction efficiency, and the effects of parameters such as flow rate, $\mathrm{pH}$, type and the least amount of acid for stripping of lead(II) from the modified disks and break through volume were examined. The maximum capacity of the membrane disks modified by $4.0 \mathrm{mg}$ of MMAB used was found to be $527 \pm 4 \mu \mathrm{g}$ of lead(II) ions. The preconcentration factor is 440 (for $2200 \mathrm{~mL}$ water sample and flow rate of $12 \mathrm{~mL} \mathrm{~min}^{-1}$ ) and detection limit of the proposed method is $85.4 \mathrm{ng} \mathrm{mL}^{-1}$. The developed method was successfully applied to the determination of lead(II) ions in blood, spinach, bean, hair, milk, pepper and various water samples.
\end{abstract}

Keywords: Lead(II), Solid phase extraction, Benzenecarbothioamide, Preconcentration, ICP-AES.

\section{INTRODUCTION}

Lead is a neurotoxin and can enter the organism primairily via alimentary and/or the respiratory tract. It can be accumulated in skeleton and lead to behavioural abnormalities, retarding intelligence and mental development [1]. This element is listed by the Enviromental Protection Agency as one of 129 priority pollutants [2]. In trace level, it decreases enzymatic and chronic exposure to lead poisoning causes nephritis, scaring and the shrinking of kidney tissues, but it is an important constituent of some alloys too [3]. Thus, the determination of trace amounts of this element, is becoming increasingly important.

The most common methods for determination of lead(II) ions are including flame and graphite furnace atomic absorption spectrometry, spectrophotometry, constant current stripping analysis, differential pulse anoding stripping voltametry, inductively coupled plasma atomic emission spectrometry and potentiometry. The sensitivity of these methods is usually insufficient for very low level monitoring of lead(II) concentration in environmental samples. Consequently, a preconcentration and matrix elemination step is usually required. The most widely used techniques for the separation and

\footnotetext{
${ }^{*}$ Address corresponding to this author at the NFCRS, Nuclear Science \& Technology Research Institute, AEOI, P.O. Box 11365-8486, Tehran, Iran; Tel: +98 21 82062514; Fax: +98 2182062539 ;

E-mail: pourjavid@gmail.com

\#Co-Author E-mail: ali_akbari_sehat@yahoo.com
}

preconcentration of trace amounts of this ion are liquidliquid extraction (LLE), absorption on various adsorbents such as thiol cotton, silica gel, silanized glass beads and amberlite XAD-4. One of widely used and fast emerging preconcentrative separation techniques for this purpose is the solid phase extraction (SPE). It is an alternative technique due to the following advantages: higher enrichment factor, absence of emulsion, safety with respect to hazardous samples, minimal costs due to low consumption of reagents, flexibility and ease of automation $[4,5]$. Hydrophobic SPE disks have been used extensively for the determination of organic environmental pollutents $[6,7]$. These disks, made of $90 \%(\mathrm{w} / \mathrm{w})$ octadecyl silane in an inert polytetrafluoroethylene (PTFE) matrix, have a typical diameter of $47 \mathrm{~mm}$ and a thickness of $0.5 \mathrm{~mm}$. Typical capacity of a disk for well-retained compounds ranges from 10 to $20 \mathrm{mg}$. The proclaimed major advantages of the SPE disks include (1) shorter sample processing time due to the large crosssectional area of the disk and decreased pressure drop, which allows the sample processing at higher flow rates, (2) decreased plugging by particles due to large cross-sectional area of the disk and (3) reduced channeling resulting from the use of smaller diameter sorbent and a greater mechanical stability of the sorbent bed [8].

We have modified the octadecyl silica membrane disks with some compounds for selective separation and preconcentration trace amounts of lead, copper 
and silver [9-12]. In the present paper, a simple SPE procedure has been developed using 4-methyl-N-\{2-(4methylbenzothioyl)aminoethyl\}benzenecarbothioamide (MMAB) (Figure 1) as modifier for lead(II) ions from aqueous solutions and real samples of blood, spinach, bean, hair, milk, pepper and various water samples. To the best of our knowledge, octadecyl silica membrane disks modified by MMAB have not been employed previously for selective separation and preconcentration of lead(II) ions from various samples. Presence of donor atoms (nitrogen and sulfur) in MMAB which form complexes with the lead(II) ions in solution, is the primary factor in extraction.

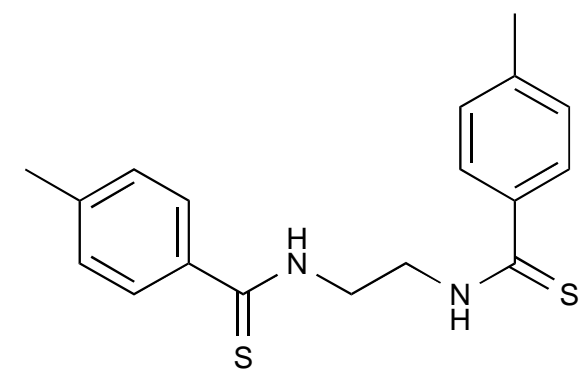

Figure 1: Structure of MMAB.

\section{EXPERIMENTAL}

\subsection{Instruments}

A Varian Liberty 150 AX Turbo ICP-AES was used for analysis. Determination of all other cations was performed under the recommended conditions for each metal. Extraction were performed with $47 \times 0.5 \mathrm{~mm}$ (diameter $\times$ thickness) Empore membrane disks containing octadecyl-bonded silica (8- $\mu \mathrm{m}$ particles $60-\AA$ pore size, $3 \mathrm{M}$ Co., Paul, MN). The disk was used in conjunction with standard Millipore 47-mm filtration apparatus. A Metrohm $691 \mathrm{pH} / \mathrm{ion}$ meter (Buchs, Switzerland) with a combined glass-calomel electrode was employed for measuring $\mathrm{pH}$ values of the test solutions.

\subsection{Reagents and Materials}

All solutions were prepared with deionized distilled water (Milli-Q Millipore $18.2 \mathrm{M} \Omega \mathrm{cm}^{-1}$ conductivity). Otherwise stated, analytical grade acids, bases, nitrate salts of metals and other chemicals used in this study were obtained for Merck. All plastic and glassware were cleaned by soaking in dilute $\mathrm{HNO}_{3}(1+9)$ and were rinsed with distilled water perior to use. MMAB was purchased from the Jaber Ibn Hayan research laboratories (Tehran, Iran).

\subsection{Test Procedure for Solid Phase Extraction of Lead(II) lons}

After placing the membrane disk in the filtration apparatus, it was washed with $10 \mathrm{~mL}$ of methanol and methanol-ethanol $(50-50 \% \mathrm{~V} / \mathrm{V})$ to remove all contaminants arising from the manufacturing process and from the environment. After drying the disk by passing air through it for several minutes, a solution of $4.0 \mathrm{mg}$ of MMAB dissolved in $4 \mathrm{~mL}$ of methanol was introduced onto the disk so that the solution was spread on the whole disk surface. The solution was allowed to penetrate inside the membrane completely without applying any vacuum. After about $1 \mathrm{~min}$, the filtration funnel containing the modified disk was transferred into an oven and the solvent was completely evaporated at $60{ }^{\circ} \mathrm{C}$. Then the sample solution containing lead(II) ions with $\mathrm{pH}$ about 6.0 (that was chosen after investigation of $\mathrm{pH}$ effect) was passed through the membrane. After the extraction, the disk was stripped from the membrane disk using minimum $5 \mathrm{~mL}$ of a $2 \mathrm{~mol} \mathrm{~L}^{-1}$ nitric acid solution. The eluent was analyzed for determination of lead concentrations by inductively coupled plasma atomic emission spectrometry $[11,12]$.

\subsection{Preconcentration Procedure}

Standard test solution (containing $10 \mu \mathrm{g} \mathrm{Pb}^{2+}$ ) was prepared and the $\mathrm{pH}$ was adjusted to optimum working $\mathrm{pH}$. This solution was permitted to flow through the modified membrane disk at optimum flow rate. The adsorbed lead(II) ions on the membrane were eluted with $5 \mathrm{~mL}$ of $2.0 \mathrm{~mol} \mathrm{~L}^{-1} \mathrm{HNO}_{3}$ solution. Lead(II) ions were determined by ICP-AES. The preconcentration factor (PF) could be calculated from the ratio of initial volume of sample to the final volume after concentration.

\subsection{Applications}

$3 \mathrm{~mL}$ of a freshly prepared mixture of concentrated $\mathrm{HNO}_{3}-\mathrm{H}_{2} \mathrm{O}_{2}(2: 1, \mathrm{v} / \mathrm{v})$ was added to triplicate $0.2 \mathrm{~mL}$ of blood samples (were directly taken into PTFE flasks). The mixture kept for $15 \mathrm{~min}$ at room temperature and then heated following a 1-stage digestion programmed at $80 \%$ of total power $(900 \mathrm{~W}), 1-2 \mathrm{~min}$ for blood samples. The resulting digested semidried mass was diluted up to $10 \mathrm{~mL}$ with $0.1 \mathrm{~mol} \mathrm{~L}^{-1}$ concentrated $\mathrm{HNO}_{3}$. A blank extraction was carried out through the complete procedure. An aliquot of $100 \mathrm{~mL}$ total blood (previously homogenized) was diluted and lead(II) ions were determined by the general procedure.The 
concentrations were obtained directly from calibration graphs after correction of the absorbance for the signal obtained from an appropriate reagent blank [13].

A $10 \mathrm{~g}$ of bean grain and $40 \mathrm{~g}$ leaves of spinach were heated in silica crucible for $3 \mathrm{~h}$ on a hot plate. The charred material was transferred to furnace and heating overnight at $650^{\circ} \mathrm{C}$. The residue of bean grain was cooled, treated with $10 \mathrm{~mL}$ concentrated nitric acid and $3 \mathrm{~mL}$ of $30 \% \mathrm{H}_{2} \mathrm{O}_{2}$, and again kept in furnace for 2 $\mathrm{h}$. The residue of spinach leaves was cooled, gain kept in furnace for $2 \mathrm{~h}$ at the same temperature to decompose organic matter completely. The final residue was treated with $3 \mathrm{~mL}$ concentrated hydrochloric acid and $2-4 \mathrm{~mL} 70 \%$ perchloric acid and heated on hot plate to expel all acid fumes so that all the metals change to respective ions. The solid residue was dissolved in water, filtered and by adjusts $\mathrm{pH}$ at 6.0 by addition of $\mathrm{KOH}$ and phosphate buffer $[14,15]$.

Hair samples $(0.5 \mathrm{~g})$ were cut into pieces no longer than $1 \mathrm{~cm}$, thoroughly washed with a mixture of ethyl ether and acetone $(3: 1, v / v)$ under continuous stirring for $10 \mathrm{~min}$, dried at $85^{\circ} \mathrm{C}$ for $1 \mathrm{~h}$, and treated with a dilute $(5 \%)$ aqueous solution of EDTA for $1 \mathrm{~h}$. The pieces were repeatedly rinsed with distilled water, and finally dried at $85^{\circ} \mathrm{C}$ for $12 \mathrm{~h}$ in an oven to determine the dry weight of the sample just before the subsequent step. Hair digestion was based on irradiation with a microwave field at $2.45 \mathrm{GHz}$. The treatment steps have done as reported with $\mathrm{HNO}_{3}, \mathrm{H}_{2} \mathrm{O}_{2}$ and $\mathrm{HF}$ [16].

$1.5 \mathrm{~mL}$ of milk samples were transferred into previously decontaminated TFM vessels and digested by means of a Microwave oven. A number of five different portions of $1 \mathrm{~mL}$, sampled from the same tube, were weighed in order to calculate the mean density of milk. The presence of fat in milk has required a strong digestion program with a reagents mixture of $5 \mathrm{~mL}$ of concentrated nitric acid $65 \%(\mathrm{v} / \mathrm{v})$ and $1 \mathrm{~mL}$ of hydrogen peroxide $40 \%(\mathrm{v} / \mathrm{v})$. After cooling, the digested solutions were quantitatively transferred in Falcon tubes of $50 \mathrm{~mL}$ by adding high purity deionized water up to a weight of $20 \mathrm{~g}$ [17].

A $100 \mathrm{mg}$ pepper was taken in a beaker and dissolved in concentrated nitric acid $(5 \mathrm{~mL})$ with heating. The solution was cooled, neutralized with $\mathrm{NaOH}$ solution, diluted and filtered. The filtrate was made to $100 \mathrm{~mL}$ with water in a calibrated flask. An aliquot (10-20 mL) of the sample solution was taken and lead(II) ions were determined by the general procedure [12].
Tap, river and spring water samples used for development of the method were collected in PTFE containers. Before the analysis, the organic content of the water samples was oxidized in the presence of $1 \%$ $\mathrm{H}_{2} \mathrm{O}_{2}$ and then concentrated nitric acid was added. These water samples were then filtered using a 0.45 $\mu \mathrm{m}$ pore size membrane filter to remove suspended particulate matter and stored in a refrigerator in the dark before analysis [18].

\section{RESULTS AND DISCUSSION}

Normally, metal ions exist in hydrated form or as complexes associated with anions with little or no tendency of transformation to polymeric matrix. To convert the metal ion to an extractable species its charge must be neutralized and some or all water of hydration be replaced. Thus, the characteristics of metal ions and functional groups and/or donor atoms (such as $\mathrm{O}, \mathrm{N}, \mathrm{P}$ and $\mathrm{S}$ ), which form complexes with the metal ions in solution, are the primary factors in extraction [19]. The selectivity of the surface with the immobilized functional groups towards metal ion(s) depends on factors like size of the modifier, activity of the loaded group and the characteristics of hard-soft acid-base $[20,21]$. The insertion of suitable specific functional groups into the polymeric matrix makes them capable of reacting with metal species under certain favorable conditions to form metal complexes [19].

Despite great improvement in sensitivity and selectivity of modern instrumental techniques of analysis for the determination of trace metals in complex matrices, the crux is separation of analyte from the bulk matrix followed by concentration prior to instrumental detection. The use of $\mathrm{C} 18$ bonded silica phase, silica gel functionalized with silane reagents and/or organic chelating groups are in frontiers for the preconcentration. Development of silica supported molecular traps through covalent grafting of organic molecules on silica surface plays important role in elimination of toxic heavy elements from wastewater. Again there is a decrease in detection limit due to extraction of the analyte component from a relatively large volume of solution into the phase of the sorbent. Better selectivity results from the geometrical features of fixing chelating groups on silica surface and complex forming properties of the chelating group [19].

Some reaserches showed that, the schiff's base compounds can form a fairly stable and selective complex with transition and heavy metal ions $[22,23]$. 
To the best of our knowledge, there is no report on the stability of MMAB complexes with metal ions. Thus, in preliminary experiments, the complexation of MMAB with a number of alkali, alkaline earth, transition and heavy metal ions was studied conductometrically in acetonitrile solution in order to obtain a clue to the stability and selectivity of the resulting complexes. In all measurements, the cell should be thermostated at the temperature of $25.0 \pm 0.1^{\circ} \mathrm{C}$, using a Phywe immersion thermostat. Intypical experiments, $25 \mathrm{~mL}$ of an ion solution $\left(1.0 \times 10^{-4} \mathrm{M}\right)$ is placed in a water-jacketed cell, equipped with a magnetic stirrer and connected to the thermostat, circulating water at the desired temperature. Then, a known amount of an MMAB $\left(1.0 \times 10^{-2} \mathrm{M}\right)$ solution is added in a stepwise manner, using a calibrated micropipette. The conductance of the solution is measured after each addition. The MMAB addition is continued until the desired MMAB-to-ion mole ratio is achieved. The $1: 1$ binding of the different cations with $\mathrm{MMAB}$ can be expressed by the following equilibrium:

$M^{n+}+M M A B \rightarrow M-M M A B^{n+}$

$K_{f}=\frac{\left[M-M M A B^{n+}\right]}{\left[M^{n+}\right][M M A B]} \times \frac{f_{\left(M-M M A B^{n+}\right)}}{f_{\left(M^{n+}\right)} f_{(M M A B)}}$

The complex formation constancy in terms of the molar conductances, $\Lambda$, can be expressed as [24]:

$$
\begin{aligned}
& K_{f}=\frac{\left[M-M M A B^{n+}\right]}{\left[M^{n+}\right][M M A B]}=\frac{\left(\Lambda_{M}-\Lambda_{o b s}\right)}{\left(\Lambda_{o b s}-\Lambda_{M-M M A B^{n+}}\right)[M M A B]} \\
& {[M M A B]=C_{M M A B}-\frac{C_{M}\left(\Lambda_{M}-\Lambda_{o b s}\right)}{\left(\Lambda_{M}-\Lambda_{M-M M A B^{n+}}\right)}}
\end{aligned}
$$

$\Lambda_{\mathrm{M}}$ is the molar conductance of the metal ions before addition of MMAB, $\Lambda_{M-M M A B}{ }^{n+}$ the molar conductance of complexed ions, $\Lambda_{\text {obs }}$ the molar conductance of the solution during titration, $\mathrm{C}_{\mathrm{MMAB}}$ the analytical concentration of MMAB added, and $C_{M}$ the analytical concentration of the metal ions. The complex formation constants $\left(\mathrm{K}_{\mathrm{f}}\right)$ were evaluated by computer fitting of equations (3) and (4) to the molar conductance-mole ratio data using a non-linear leastsquares program KINFIT [25] and the results are summarized in Table 1. This behaviour indicated that the MMAB complex was less mobile than the free solvated $\mathrm{Pb}^{2+}$ cation. As can be seen, the MMAB could act as a suitable complexing agent for preconcentration and separation of lead(II) ions via SPE, by using octadecyl bonded silica membrane disks.
Table 1: Formation Constants of Complexation of MMAB and Different Cations in Acetonitrile Solution

\begin{tabular}{|c|c|c|c|}
\hline Cation & $\log \mathrm{K}_{\mathrm{f}}$ & Cation & $\log \mathrm{K}_{\mathbf{f}}$ \\
\hline \hline $\mathrm{Na}^{+}$ & $2.11 \pm 0.05$ & $\mathrm{Zn}^{2+}$ & $2.83 \pm 0.01$ \\
\hline $\mathrm{K}^{+}$ & $1.82 \pm 0.06$ & $\mathrm{Ni}^{2+}$ & $3.04 \pm 0.05$ \\
\hline $\mathrm{Ca}^{2+}$ & $2.33 \pm 0.03$ & $\mathrm{~Pb}^{2+}$ & $6.03 \pm 0.02$ \\
\hline $\mathrm{Ba}^{2+}$ & $2.24 \pm 0.07$ & $\mathrm{Cd}^{2+}$ & $3.89 \pm 0.03$ \\
\hline $\mathrm{Cu}^{2+}$ & $4.27 \pm 0.06$ & $\mathrm{Fe}^{2+}$ & $2.46 \pm 0.02$ \\
\hline $\mathrm{Co}^{2+}$ & $3.41 \pm 0.05$ & $\mathrm{Mn}^{2+}$ & $2.92 \pm 0.06$ \\
\hline
\end{tabular}

\section{1. pH Studies on the Lead(II) lons Removal}

For solid phase extraction of the heavy metal ions based on chelating, the $\mathrm{pH}$ of the aqueous solution is one of the main factor quantitative recoveries of the analytes. Also, the formation of the metal ion complex and the maximum separation efficienncy can be achieved by optimization of $\mathrm{pH}$. The influence of $\mathrm{pH}$ on the retention of lead(II) ions extraction was studied by applying the proposed procedure to $20 \mathrm{~mL}$ of sample solutions $\left(1.0 \mathrm{\mu g} \mathrm{L}^{-1} \mathrm{~Pb}^{2+}\right.$ ions). The $\mathrm{pH}$ of each solution was adjusted to values ranging from 2.0 to 8.0 with $\mathrm{HNO}_{3}$ and $\mathrm{KOH}$ solutions. According to the results (Figure 2), quantitative recovery values for the lead(II) ions were obtained through the $\mathrm{pH}$ range of 3.5-8.0. At lower $\mathrm{pH}(<3.5)$, the nitrogen and/or sulfur atoms of the MMAB could be protonated and reduce the stability of complex formation between MMAB and lead(II) ions. The higher $\mathrm{pH}$ values $(>8.0)$ were not tested because of the possibility of the hydrolysis of octadecyl silica in the disks. Also, at $\mathrm{pH}$ values higher than 8.0 , lead(II)

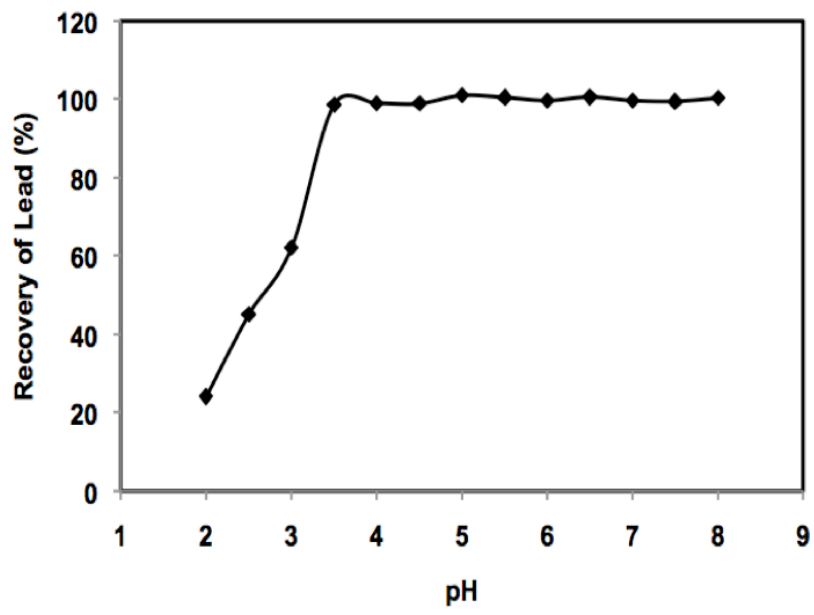

Figure 2: Effect of $\mathrm{pH}$ on recovery of the lead(II) ions (other conditions: $1.0 \mu \mathrm{g} \mathrm{L}^{-1}$ of $\mathrm{Pb}^{2+}$; sample flow rate: $5 \mathrm{~mL} \mathrm{~min}{ }^{-1}$; eluent flow rate: $5 \mathrm{~mL} \mathrm{~min}^{-1}$; sample volume: $20 \mathrm{~mL}$; room temperature; $n=3$ ). 
ions from complexes and precipitates with hydroxide ions and their retention is changed and the recovery of the method $s$ decreased. So, all subsequent studies were carried out at $\mathrm{pH} 6.0$.

\subsection{Influence of Modifier Amount}

The proposed method is based on sorption of lead(II) ions on modified membrane disk. In order to investigate the effects of the amount of modifier on the quantitative extraction of lead(II) ions by membrane disk, the extraction was conducted by varying the amounts of MMAB at $5.0 \mathrm{~mL} \mathrm{~min}{ }^{-1}$ flow rates of sample and eluent solutions. Firstly, some works were carried out without ligand at $\mathrm{pH}$ 6.0. As seen in Figure 3, the lead(II) ions were not quantitatively recovered $(<5 \%)$ without MMAB. The recovery values were found quantitative by using at least $4.0 \mathrm{mg}$ of MMAB. With a lower amount, the recovery was decreased, because the extent of complexation and retention of lead(II) ions on the modified membrane is low. On this base, subsequent extraction experiments were carried out with $4.0 \mathrm{mg}$ of MMAB.

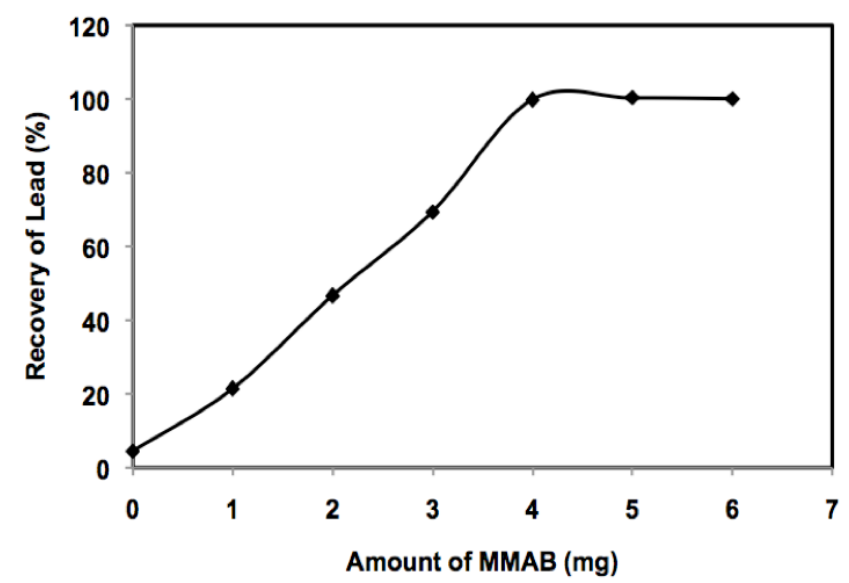

Figure 3: Influence of amount of MMAB on lead(II) ions recovery (other conditions: $1.0 \mu \mathrm{g} \mathrm{L}^{-1}$ of $\mathrm{Pb}^{2+}$; sample flow rate: $5 \mathrm{~mL} \mathrm{~min}^{-1}$; eluent flow rate: $5 \mathrm{~mL} \mathrm{~min}^{-1}$; sample volume: $20 \mathrm{~mL} ; \mathrm{pH}=6.0$; room temperature; $\mathrm{n}=3$ ).

\subsection{Studies of Various Eluent Agents}

The selection of suitable eluent was a difficult problem. The nature and concentration of eluting agents were found to have a significant effect on the desorption process of the adsorbed ions from the modified membrane. A satisfactory eluent should effectively elute the adsorbed analytes with small volume, which is needed for a high preconcentration factor, and should not affect the accurate determination of the analytes and destroy life time and reusability of SPE [26]. Because the adsorption of lead(II) ions is not acceptable at lower $\mathrm{pH}$, various concentrations and various volumes of $\mathrm{HCl}, \mathrm{HNO}_{3}$ and $\mathrm{CH}_{3} \mathrm{COOH}$ were tested for desorption of retained lead(II) from the modified membrane disk. As it is observed in Table 2, $\mathrm{HNO}_{3}$ showed the best quantitative elution effect in firs experiments and therefore it was selected as an eluent for further applications. After that, the experiments were carried out with acidic solutions at the concentration range of 1.0-3.0 $\mathrm{mol} \mathrm{L}^{-1}$ and volume of 2$8 \mathrm{~mL}$ for selecting the best concentration and volume of $\mathrm{HNO}_{3}$. The recovery values were increased with increasing of acid concentration and volume. As it is obvious that among three different acid solutions used, $5 \mathrm{~mL}$ of about $2.0 \mathrm{~mol} \mathrm{~L}^{-1}$ nitric acid can accomplish the quantitative elution of lead(II) from the membrane disk. The effect of $\mathrm{HNO}_{3}$ as an eluent could be due to its ability to decompose the complex of lead(II)-MMAB and produce free lead(II) ions that can easily pass through the membrane.

Table 2: Effect of Type and Concentration of Eluting Agent on Recoveries of Lead(II) lons ${ }^{a}$

\begin{tabular}{|c|c|c|}
\hline Eluent & Volume $(\mathrm{mL})$ & Recovery (\%) \\
\hline \hline $\mathrm{HCl}\left(1 \mathrm{~mol} \mathrm{~L}^{-1}\right)$ & 2 & $67.1 \pm 0.7$ \\
\hline $\mathrm{HNO}_{3}\left(1 \mathrm{~mol} \mathrm{~L}^{-1}\right)$ & 2 & $74.3 \pm 0.4$ \\
\hline $\mathrm{CH}_{3} \mathrm{COOH}\left(1 \mathrm{~mol} \mathrm{~L}^{-1}\right)$ & 2 & $61.6 \pm 0.3$ \\
\hline $\mathrm{HNO}_{3}\left(1 \mathrm{~mol} \mathrm{~L}^{-1}\right)$ & 5 & $96.4 \pm 0.1$ \\
\hline $\mathrm{HNO}_{3}\left(1 \mathrm{~mol} \mathrm{~L}^{-1}\right)$ & 8 & $99.5 \pm 0.5$ \\
\hline $\mathrm{HNO}_{3}\left(2 \mathrm{~mol} \mathrm{~L}^{-1}\right)$ & 3 & $93.7 \pm 0.5$ \\
\hline $\mathrm{HNO}_{3}\left(2.5 \mathrm{~mol} \mathrm{~L}^{-1}\right)$ & 3 & $98.3 \pm 0.2$ \\
\hline $\mathrm{HNO}_{3}\left(3 \mathrm{~mol} \mathrm{~L}^{-1}\right)$ & 3 & $100.4 \pm 0.6$ \\
\hline $\mathrm{HNO}_{3}\left(2.5 \mathrm{~mol} \mathrm{~L}^{-1}\right)$ & 4 & $99.5 \pm 0.3$ \\
\hline $\mathrm{HNO}_{3}\left(2.0 \mathrm{~mol} \mathrm{~L}^{-1}\right)$ & 5 & $100.2 \pm 0.4$ \\
\hline $\mathrm{HNO}_{3}\left(2.0 \mathrm{~mol} \mathrm{~L}^{-1}\right)$ & 6 & $98.8 \pm 0.1$ \\
\hline
\end{tabular}

anitial samples contained $1.0 \mu \mathrm{g} \mathrm{L}^{-1} \mathrm{~Pb}^{2+}$ ions (in $20 \mathrm{~mL}$ of solution). "The values following " \pm " is the standard deviation $(n=3)$.

\subsection{Influence of Flow Rate}

After optimization of the eluent volume and concentration, the effect of flow rate on the adsorption of lead(II) ions was also investigated. It affects the retention of cations on the adsorbent and the duration of complete analysis. While the recovery increases with the decreasing flow rate, the preconcentration time increases. The influence of flow rates of the sample and eluent solutions from the modified membrane disk on the retention and recovery of lead(II) ions was investigated and the results (Figure 4) showed that the retention of lead(II) ions is not affected by the sample 
solution flow rate in the range of $1-12 \mathrm{~mL} \mathrm{~min}^{-1}$, by the membrane disk that modified with $4.0 \mathrm{mg}$ of MMAB. At higher flow rate than $12 \mathrm{~mL} \mathrm{~min}{ }^{-1}$ the extraction and stripping of lead(II) reduced considerably, because the sample solution passes through the membrane disk faster and there is not enough time for equilibration between the lead(II) ions and MMAB. Therefore, to increase the speed of operation, a sample flow rate of $12 \mathrm{~mL} \mathrm{~min}^{-1}$ was selected as the optimum value. The flow rate of eluent solution was examined in the range of $1-10 \mathrm{~mL} \mathrm{~min}{ }^{-1}$. After $8 \mathrm{~mL} \mathrm{~min}{ }^{-1}$ of eluent solution, the recovery values were not quantitative. For the all experiments, 12 and $8 \mathrm{~mL} \min ^{-1}$ was selected as sample and eluent flow rate respectively.

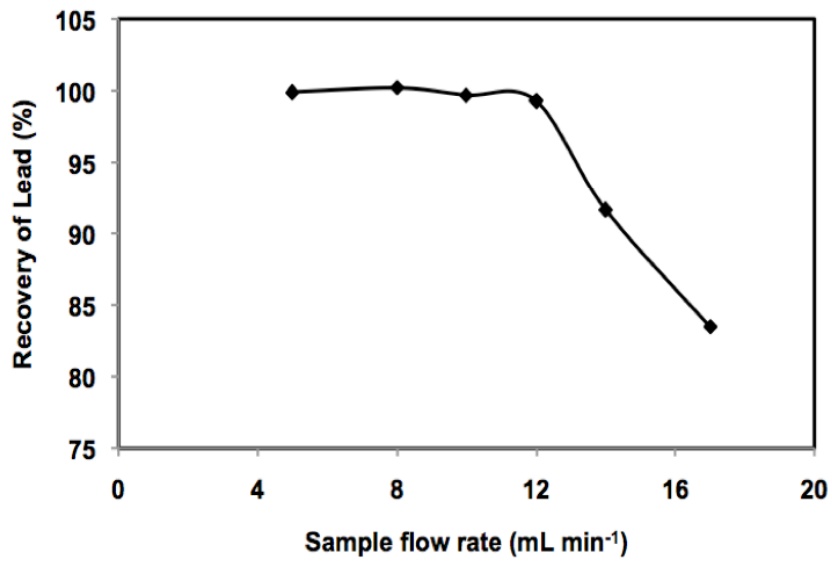

Figure 4: Effect of sample and eluent flow rate on adsorption

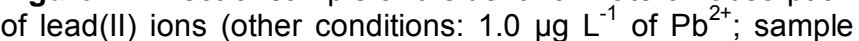
volume: $20 \mathrm{~mL} ; \mathrm{pH}=6.0$; room temperature; $\mathrm{n}=3$ ).

\subsection{Effect of the Volume of Sample Solutions}

A higher preconcentration factor can be obtained by increasing the sample to eluent volume ratio by either decreasing the eluent volume and/or increasing the sample volume. Therefore, the effect of sample volume on the retention behavior of the lead(II) ions was investigated by passing $100-2800 \mathrm{~mL}$ of solutions. As shown in Figure 5, the recovery was found to be stable until $2200 \mathrm{~mL}$. Consequently, by considering the final elution volume of $5 \mathrm{~mL}$ and the sample solution volume of $2200 \mathrm{~mL}$, an preconcentration factor 440 is obtained.

\subsection{Linear Range and Detection Limit of the Proposed Method}

By employing the optimum experimental conditions, the calibration graphs for lead(II) ions were obtained. The calibration graph exhibits linearity over the range of $0.1-250 \mathrm{\mu g} \mathrm{L}^{-1}$ with a correlation of 0.9997 . The limit of detection (LOD) of the proposed method for the determination of lead(II) was studied. The LOD obtained from $\mathrm{C}_{\mathrm{LOD}}=\mathrm{K}_{\mathrm{b}} \mathrm{S}_{\mathrm{b}} \mathrm{m}^{-1}$ for a numerical factor $\mathrm{K}_{\mathrm{b}}$ $=3$ and preconcentration factor of 440 , is $85.4 \mathrm{ng} \mathrm{L}^{-1}$. $K_{b}$ is confidence factor (the factor $K_{b}$ is most often chosen to be 2 or 3 ), $S_{b}$ is the standard deviation of the blank measurement, and $\mathrm{m}$ is the slope of the calibration curve at particular concentration $(n=5)$.

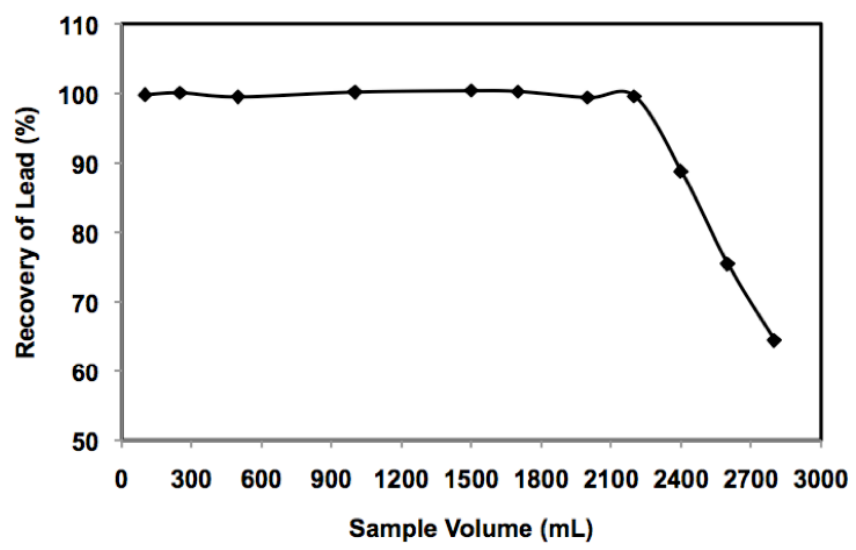

Figure 5: Effect of sample solution volume (other conditions: $10 \mu \mathrm{g}$ of $\mathrm{Pb}^{2+}$; sample flow rate: $12 \mathrm{~mL} \mathrm{~min}^{-1}$; eluent flow rate: $8 \mathrm{~mL} \mathrm{~min}^{-1} ; \mathrm{pH}=6.0$; room temperature; $\mathrm{n}=3$ ).

\subsection{Retention Capaciy of Membrane}

Retention capacity is an important parameter for the evaluation of adsorbent. It is the maximum metal ion quantity taken up by modified membrane disk. In order to study the maximum capacity of the membrane disk modified by $4.0 \mathrm{mg}$ of MMAB, $50 \mathrm{~mL}$ portions of an aqueous solution containing $1500 \mu \mathrm{g}$ lead(II) ions was passed through the disk, followed by determination of the retained lead(II) ions using ICP-AES. The maximum capacity was found to the $527 \pm 4 \mu \mathrm{g}$ of $\mathrm{Pb}^{2+}$ ions on the disk. This indicates that the membrane disk is capable of absorbing large amounts of lead(II) ions.

\subsection{Effect of Interfering lons}

Because of the presence of other elements in real samples, the determination and preconcentration of lead(II) ions are difficult. Therefore, the effect of common coexisting cations (and anions) on the adsorption of lead(II) ions on the modified membrane disk were investigate. Metal cations were added individually to $50 \mathrm{~mL}$ sample solutions containing 1.0 $\mu \mathrm{g} \mathrm{L}^{-1} \mathrm{~Pb}^{2+}$ ions. The tolerance limit was considered if it resulted in $\pm 3 \%$ variation in sorption efficiency of $\mathrm{Pb}^{2+}$. It has been found (from Table 3 ) that recovery of lead(II) was almost quantitative in presence of foreign ions and therefore useful for the analysis of this ions in real samples. 
Table 3: Tolerance Limits for Coexisting lons in Adsorption of Lead(II) lons ${ }^{\text {a }}$

\begin{tabular}{|c|c|c|}
\hline Foreign ion & Interferent $/$ ion ratio $\left(\mathbf{M}^{\mathrm{n}+} / \mathbf{P b}^{2+}\right)$ & $100.2 \pm 1.4$ \\
\hline \hline $\mathrm{Na}^{+}$ & 30000 & $100.0 \pm 3.1$ \\
\hline $\mathrm{K}^{+}$ & 30000 & $99.8 \pm 2.2$ \\
\hline $\mathrm{Ca}^{2+}$ & 30000 & $99.8 \pm 2.5$ \\
\hline $\mathrm{Mg}^{2+}$ & 30000 & $101.2 \pm 1.3$ \\
\hline $\mathrm{Sr}^{2+}$ & 30000 & $99.9 \pm 2.2$ \\
\hline $\mathrm{Zn}^{2+}$ & 5000 & $99.7 \pm 3.1$ \\
\hline $\mathrm{Ag}^{+}$ & 5000 & $100.6 \pm 1.8$ \\
\hline $\mathrm{Fe}^{2+}$ & 5000 & $100.4 \pm 2.6$ \\
\hline $\mathrm{Mn}^{2+}$ & 5000 & $99.5 \pm 1.4$ \\
\hline $\mathrm{Co}^{2+}$ & 5000 & $98.7 \pm 1.6$ \\
\hline $\mathrm{Ni}^{2+}$ & 5000 & $99.2 \pm 1.5$ \\
\hline $\mathrm{Cd}^{2+}$ & 300 & $98.8 \pm 1.0$ \\
\hline $\mathrm{Cu}^{2+}$ & 300 & \\
\hline
\end{tabular}

anitial samples contained $1.0 \mu \mathrm{g} \mathrm{L}^{-1} \mathrm{~Pb}^{2+}$ ions.

'The values following " \pm " is the standard deviation $(n=3)$.

\subsection{Analysis of Real Samples}

Various amounts of lead(II) ions were spiked to blood, spinach, bean, hair, milk, pepper and some water samples. Then the procedure presented was applied to the determination of lead(II) in these samples. The results are given in Table 4 . As can be seen, the results obtained by the proposed method and ICP-AES are in satisfactory agreement with the added lead(II) ions amounts. These results confirm the validity of the proposed method.

Table 4: Recovery Studies of Lead(II) lons Determination in Real Samples ${ }^{a}$

\begin{tabular}{|c|c|c|c|}
\hline Sample & Added value & Found value $^{\text {b }}$ & Recovery (\%) $^{\text {(\%ood }}$ \\
\hline \hline Spinach & 0.0 & $0.028 \pm 0.007$ & - \\
& 0.2 & $0.233 \pm 0.010$ & - \\
\hline Bean & 0.0 & $0.166 \pm 0.008$ & 102.5 \\
& 0.2 & $0.370 \pm 0.034$ & - \\
\hline Hair & 0.0 & $0.083 \pm 0.011$ & - \\
& 0.3 & $0.395 \pm 0.008$ & 103 \\
\hline Milk & 0.0 & $0.196 \pm 0.021$ & - \\
& 0.3 & $0.505 \pm 0.085$ & 104.7 \\
\hline Hot pepper & 0.0 & $0.061 \pm 0.014$ & - \\
& 0.3 & $0.375 \pm 0.006$ & - \\
\hline Tap water & 0.0 & $1.250 \pm 0.012$ & 99 \\
\hline River water & 0.5 & $1.769 \pm 0.026$ & - \\
& 0.0 & $0.024 \pm 0.005$ & 100.4 \\
\hline Spring water & 0.5 & $0.519 \pm 0.014$ & - \\
& 0.0 & $0.043 \pm 0.005$ & 101.6 \\
\hline
\end{tabular}

${ }^{\text {a }}$ The unit for solid samples is $\mu \mathrm{g} \mathrm{g}^{-1}$ and for liquid samples is $\mu \mathrm{g} \mathrm{mL}^{-1}$.

"The values following " \pm " is the standard deviation $(n=3)$. 
Table 5: Comparative Data from Published Methods on Solid Phase Extraction of Lead lons

\begin{tabular}{|c|c|c|c|c|c|c|}
\hline Adsorbent & pH & Eluent & $\begin{array}{l}\text { Flow rate } \\
\left(\mathrm{mL} \mathrm{min}^{-1}\right)\end{array}$ & $\mathrm{PF}^{\mathrm{a}}$ & $\begin{array}{c}\operatorname{LOD}^{b} \\
\left(\mu \mathrm{g} \mathrm{mL}^{-1}\right)\end{array}$ & Reference \\
\hline $\begin{array}{c}\text { Sodium dodecyl sulfate coated } \\
\text { PVC }\end{array}$ & 7 & $\begin{array}{l}10 \mathrm{~mL} \mathrm{HNO}_{3} \\
\left(3 \mathrm{~mol} \mathrm{~L}^{-1}\right)\end{array}$ & - & 50 & 0.29 & 14 \\
\hline Graphene & 6 & $\begin{array}{l}2 \mathrm{~mL} \mathrm{HNO}_{3} \\
\left(2 \mathrm{~mol} \mathrm{~L}^{-1}\right)\end{array}$ & 2 & 125 & 0.61 & 18 \\
\hline Solid sulfur & 8 & $\begin{array}{l}2 \mathrm{~mL} \mathrm{HNO}_{3} \\
\left(1 \mathrm{~mol} \mathrm{~L}^{-1}\right)\end{array}$ & 1 & 250 & 3.2 & 27 \\
\hline Oxidized SWCNTs ${ }^{c}$ & $7-9$ & $\begin{array}{l}2 \mathrm{~mL} \mathrm{HNO}_{3} \\
\left(0.5 \mathrm{~mol} \mathrm{~L}^{-1}\right)\end{array}$ & 1.2 & 50 & 0.005 & 28 \\
\hline $\begin{array}{l}\text { 1-acylthiosemicarbazide modified } \\
\text { activated carbon }\end{array}$ & 3 & $\begin{array}{c}3 \mathrm{~mL} \mathrm{CS}\left(\mathrm{NH}_{2}\right)_{2} \\
(2 \%) \text { and } \mathrm{HNO}_{3} \\
\left(2 \mathrm{~mol} \mathrm{~L}^{-1}\right)\end{array}$ & 1 & 100 & 0.45 & 29 \\
\hline $\begin{array}{l}\text { 2-aminoacetylthiophenol modified } \\
\text { polyurethane foam }\end{array}$ & 5 & $\begin{array}{l}6 \mathrm{~mL} \mathrm{HNO}_{3} \\
\left(1 \mathrm{~mol} \mathrm{~L}^{-1}\right)\end{array}$ & 3 & 167 & 0.066 & 30 \\
\hline Modified nanometer alumina & $7-8$ & $\begin{array}{l}2 \mathrm{~mL} \mathrm{HNO}_{3} \\
\left(2 \mathrm{~mol} \mathrm{~L}^{-1}\right)\end{array}$ & 3 & 250 & 0.17 & 31 \\
\hline MWCNTs $^{d}$ & 9 & $\begin{array}{l}5 \mathrm{~mL} \mathrm{HNO}_{3} \\
\left(1 \mathrm{~mol} \mathrm{~L}^{-1}\right)^{\mathrm{e}}\end{array}$ & 1 & 20 & 8.0 & 32 \\
\hline $\mathrm{MnO}_{2}$ coated carbon nanotubes & 6 & $\begin{array}{l}1.5 \mathrm{~mL} \mathrm{HNO}_{3} \\
\left(1.5 \mathrm{~mol} \mathrm{~L}^{-1}\right)\end{array}$ & 2.5 & 100 & 4.4 & 33 \\
\hline $\begin{array}{c}\text { 2-(2,4-dichlorobenzylideneamino) } \\
\text { banzenthiol modified Duolite XAD } \\
761\end{array}$ & 7 & $\begin{array}{l}10 \mathrm{~mL} \mathrm{HNO}_{3} \\
\left(4 \mathrm{~mol} \mathrm{~L}^{-1}\right)\end{array}$ & $2-3$ & 150 & 2.9 & 34 \\
\hline $\begin{array}{l}\text { Poly(2-amino thiophenol ) modified } \\
\text { MWCNTs }\end{array}$ & 6 & $\begin{array}{c}7.5 \mathrm{~mL} \mathrm{HNO}_{3} \\
(10 \%(\mathrm{v} / \mathrm{v}))\end{array}$ & $0.5-2$ & 280 & 1.0 & 35 \\
\hline $\begin{array}{l}\text { Benzenecarbothioamide modified } \\
\text { octadecyl silica membrane disk }\end{array}$ & $3.5-8$ & $\begin{array}{l}5 \mathrm{~mL} \mathrm{HNO}_{3} \\
\left(2 \mathrm{~mol} \mathrm{~L}^{-1}\right)\end{array}$ & 12 & 440 & 0.085 & Current work \\
\hline
\end{tabular}

${ }^{\mathrm{a}}$ Preconcentration factor.

bimit of detection.

'Single-walled carbon nanotubes.

${ }^{\mathrm{d}}$ Multi-walled carbon nanotubes.

${ }^{\mathrm{e}}$ in acetone.

\section{CONCLUSION}

A proposed procedure provides a simple, economical, rapid, and precise method for the preconcentration and determination of lead(II) ions using an SPE method with octadecyl-bonded silica membrane disks modified by 4-methyl-N-\{2-(4methylbenzothioyl) aminoethyl\}benzenecarbothioamide. This technique was successfully applied for separation, determination and preconcentration of lead(II) ions in various samples, namely blood, spinach, bean, hair, milk, pepper and some water samples. A comparison of the $\mathrm{pH}$, eluent flow rate, preconcentration factor and limit of detection of represented method with other SPE methods (with different adsorbent) reported in the literature [14, 18, 27-35] was given in Table 5. Higher preconcentration factor, faster flow rate, wider $\mathrm{pH}$ range and comparable limit of detection are some of the advantaged of proposed method. In short, this method is suitable for preconcentration and separation of trace and ultra trace amounts of lead(II) ions in real samples.

\section{ACKNOWLEDGEMENT}

Authors wish to express their deep thanks to Taherehsadat Razavi, Mohammad Rezaee and Majid Haji Hosseini for intellectual support of research work.

\section{REFERENCES}

[1] Seiler HG, Sigel A, Sigel H. Handbook on toxicity of inorganic compounds. Marcel Dekker. New York 1998.

[2] U.S. Environmental Protection Agency. Water quality criteria summary list 1991.

[3] Beyer NW, Spann JW, Sileo L, Franson JC. Lead poisoning in six captive avian species. Arch Environ Con Tox 1988; 17: 121-30. http://dx.doi.org/10.1007/BF01055162

[4] Hennion MC. Solid-phase extraction: method development, sorbents and coupling with liquid chromatography. $J$ Chromatogr A 1999; 856: 3-54.

http://dx.doi.org/10.1016/S0021-9673(99)00832-8 
[5] Daniel S, Praveen RS, Rao TP. Ternary ion-association complex based ion imprinted polymers (IIPs) for trace determination of palladium(II) in environmental samples. Anal Chim Acta 2006; 570: 79-87.

http://dx.doi.org/10.1016/j.aca.2006.04.007

[6] Cai Y, Baynon JM. Simultaneous Speciation of butyl-, phenyl-, and cyclohexyltin compounds in aqueous matrices using ethylation followed by solid-phase trace enrichment, SFE, and GC determination. J Chromatogr Sci 1995; 33: 8997.

[7] Yamini Y, Alizadeh N, Shamsipur M. Solid phase extraction and determination of ultra trace amounts of mercury(II) using octadecyl silica membrane disks modified by hexathia-18crown-6-tetraone and cold vapour atomic absorption spectrometry. Anal Chim Acta 1997; 355: 69-74.

http://dx.doi.org/10.1016/S0003-2670(97)81613-3

[8] Poole CF, Poole SK, Seibert DS, Chapman CM. Determination of kinetic and retention properties of cartridge and disk devices for solid-phase extraction. J Chromatogr B 1997; 689: 245-59.

http://dx.doi.org/10.1016/S0378-4347(96)00282-4

[9] Ghasemi Z, Basiripour F, Poursaberi T, et al. Preconcentration of trace amounts of copper in aqueous samples by octadecyl silica membrane modified disks and determination by flame atomic absorption spectrometry. Int $\mathrm{J}$ Environ An Ch 2001; 81: 233-42.

http://dx.doi.org/10.1080/03067310108044345

[10] Shamsipur M, Javanbakht M, Ghasemi Z, Ganjali MR, Lippolis V, Garau A. Separation, preconcentration and determination of trace amounts of silver ion in aqueous samples using octadecyl silica membrane disks modified with some recently synthesized mixed aza-thioether crowns containing 1,10-phenanthroline sub-unit and atomic absorption spectrometry. Sep Purif Technol 2002; 28: 141-7. http://dx.doi.org/10.1016/S1383-5866(02)00046-1

[11] Ganjali MR, Pourjavid MR, Haji-Agha Babaei L, SalavatiNiasari M. Octadeyl silica membrane disks modified with a new schiff's base for the preconcentration of lead and copper before their determination in water samples. Ann Chim Rome 2004; 94: 447-56.

http://dx.doi.org/10.1002/adic.200490054

[12] Ganjali MR, Pourjavid MR, Haji-Agha Babaei L, SalavatiNiasari M. Ultra-trace monitoring of copper in environmental and biological samples by inductively coupled plasma atomic emission spectrometry after separation and preconcentration by using octadecyl silica membrane disks modified by a new schiff's base. Quim Nova 2004; 27: 213-7. http://dx.doi.org/10.1590/S0100-40422004000200008

[13] Shah F, Kazi TG, Afridi HI, Naeemullah, Arain MB, Baig JA. Cloud point extraction for determination of lead in blood samples of children, using different ligands prior to analysis by flame atomic absorption spectrometry: A multivariate study. J Hazzard Mater 2011; 192: 1132-9.

http://dx.doi.org/10.1016/j.jhazmat.2011.06.017

[14] Marahel F, Ghaedi M, Shokrollahi A, Montazerozohori M, Davoodi S. Sodium dodecyl sulfate coated poly (vinyl) chloride: An alternative support for solid phase extraction of some transition and heavy metals. Chemosphere 2009; 74 : 583-9.

http://dx.doi.org/10.1016/j.chemosphere.2008.09.034

[15] Ghaedi M, Niknam K, Shokrollahi A, Niknam E, Rajabi HR, Soylak M. Flame atomic absorption spectrometric determination of trace amounts of heavy metal ions after solid phase extraction using modified sodium dodecyl sulfate coated on alumina. J Hazzard Mater 2008; 155: 121-7. http://dx.doi.org/10.1016/j.jhazmat.2007.11.038

[16] Sanna E, Liguori A, Palmas L, Soro MR, Floris G. Blood and hair lead levels in boys and girls living in two Sardinian towns at different risks of lead pollution. Ecotox Environ Safe 2003; 55: 293-9.

http://dx.doi.org/10.1016/S0147-6513(02)00072-6
[17] D'llio S, Petrucci F, Amato MD, Gregorio MD, Senofonte O, Violante N. Method validation for determination of arsenic, cadmium, chromium and lead in milk by means of dynamic reaction cell inductively coupled plasma mass spectrometry. Anal Chim Acta 2008; 624: 59-67. http://dx.doi.org/10.1016/..aca.2008.06.024

[18] Wang Y, Gao S, Zang X, Li J, Ma J. Graphene-based solidphase extraction combined with flame atomic absorption spectrometry for a sensitive determination of trace amounts of lead in environmental water and vegetable samples. Anal Chim Acta 2012; 716: 112-8.

http://dx.doi.org/10.1016/j.aca.2011.12.007

[19] Jal PK, Patel S, Mishra BK. Chemical modification of silica surface by immobilization of functional groups for extractive concentration of metal ions. Talanta 2004; 62: 1005-28. http://dx.doi.org/10.1016/j.talanta.2003.10.028

[20] Mahmoud ME. Comparison of metal uptake properties of silica gel-bound ion exchangers and some amine derivatives. Anal Lett 1996; 29: 1791-804. http://dx.doi.org/10.1080/00032719608001524

[21] Mahmoud ME, Soliman EM. Silica-immobilized formylsalicylic acid as a selective phase for the extraction of iron(III). Talanta 1997; 44: 15-22.

http://dx.doi.org/10.1016/S0039-9140(96)01960-1

[22] Poursaberi $T$, Hajiagha-Babaei L, Yousefi $M$, et al. The synthesis of a new thiophene derivative schiff's base and its use in preparation of copper-ion selective electrodes. Electroanal 2001; 13: 1513-7. http://dx.doi.org/10.1002/15214109(200112)13:18<1513::AID-ELAN1513>3.0.CO;2-X

[23] Ganjali MR, Zargazi MH, Mohajeri A. Thermodynamic study of the interaction between some recently synthesized benzosubstituted macrocyclic diamides with some pyridinium ion derivatives in acetonitrile solution. Polish J Chem 2001; 75: 743-9

[24] Takeda K. Thermodynamic study for dibenzo-24-crown-8 complexes with alkali metal ions in nonaqueous solvents. Bull Chem Soc Jpn 1983; 56: 3600-2. http://dx.doi.org/10.1246/bcsj.56.3600

[25] Dye JL, Nicely VA. A general purpose curve fitting program for class and research use. J Chem Educ 1971; 48: 443. http://dx.doi.org/10.1021/ed048p443

[26] Ghaedi M, Niknam K, Shokrollahi A, Niknam E, Rajabi HR, Soylak M. Flame atomic absorption spectrometric determination of trace amounts of heavy metal ions after solid phase extraction using modified sodium dodecyl sulfate coated on alumina. J Hazzard Mater 2008; 155: 121-7. http://dx.doi.org/10.1016/i.jhazmat.2007.11.038

[27] Parham H, Pourreza N, Rahbar N. Solid phase extraction of lead and cadmium using solid sulfur as a new metal extractor prior to determination by flame atomic absorption spectrometry. J Hazzard Mater 2009; 163: 588-92. http://dx.doi.org/10.1016/i.jhazmat.2008.07.007

[28] Chen S, Liu C, Yang M, Lu D, Zhu L, Wang Z. Solid-phase extraction of $\mathrm{Cu}, \mathrm{Co}$ and $\mathrm{Pb}$ on oxidized single-walled carbon nanotubes and their determination by inductively coupled plasma mass spectrometry. J Hazzard Mater 2009; 170: 24751.

http://dx.doi.org/10.1016/j.jhazmat.2009.04.104

[29] Gao R, Hu Z, Chang X, et al. Chemically modified activated carbon with 1-acylthiosemicarbazide for selective solid-phase extraction and preconcentration of trace $\mathrm{Cu}(\mathrm{II}), \mathrm{Hg}(\mathrm{II})$ and $\mathrm{Pb}$ (II) from water samples. J Hazzard Mater 2009; 172: 3249.

http://dx.doi.org/10.1016/j.jhazmat.2009.07.014

[30] Burham N. Separation and preconcentration system for lead and cadmium determination in natural samples using 2aminoacetylthiophenol modified polyurethane foam. Desalination 2009; 249: 1199-205

http://dx.doi.org/10.1016/j.desal.2009.04.009 
[31] Ezoddin M, Shemirani F, Abdi K, Khosravi Saghezchi M, Jamali MR. Application of modified nano-alumina as a solid phase extraction sorbent for the preconcentration of $\mathrm{Cd}$ and $\mathrm{Pb}$ in water and herbal samples prior to flame atomic absorption spectrometry determination. J Hazzard Mater 2010; 178: 900-5.

http://dx.doi.org/10.1016/.j.jhazmat.2010.02.023

[32] Ozcan SG, Satiroglu N, Soylak M. Column solid phase extraction of iron(III), copper(II), manganese(II) and lead(II) ions food and water samples on multi-walled carbon nanotubes. Food Chem Toxicol 2010; 48: 2401-6. http://dx.doi.org/10.1016/i.fct.2010.05.078

[33] Yang B, Gong Q, Zhao L, et al. Preconcentration and determination of lead and cadmium in water samples with a $\mathrm{MnO}_{2}$ coated carbon nanotubes by using ETAAS. Desalination 2011; 278: 65-9.

http://dx.doi.org/10.1016/j.desal.2011.05.010
[34] Marahel F, Ghaedi M, Montazerozohori M, Nejati Biyareh M, Nasiri Kokhdan S, Soylak M. Solid-phase extraction and determination of trace amount of some metal ions on Duolite XAD 761 modified with a new Schiff base as chelating agent in some food samples. Food Chem Toxicol 2011; 49: 208-14. http://dx.doi.org/10.1016/j.fct.2010.10.018

[35] Nabid MR, Sedghi R, Bagheri A, et al. Preparation and application of poly(2-amino thiophenol)/MWCNTs nanocomposite for adsorption and separation of cadmium and lead ions via solid phase extraction. J Hazzard Mater 2012; 203-204: 93-100.

http://dx.doi.org/10.1016/j.jhazmat.2011.11.096 